\title{
MicroRNAs are Novel Biomarkers for Detection of Colorectal Cancer
}

\author{
Muhammad Imran Aslam ${ }^{1,2}$, Maleene Patel ${ }^{12}$, Baljit Singh ${ }^{1,2}$, \\ John Stuart Jameson ${ }^{2}$ and James Howard Pringle ${ }^{1}$ \\ ${ }^{1}$ Department of Cancer Studies and Molecular Medicine, University of Leicester, \\ Robert Kilpatrick Clinical Sciences Building, Leicester Royal Infirmary, \\ ${ }^{2}$ Department of Colorectal Surgery, University Hospitals of Leicester NHS Trust, \\ Leicester General Hospital, Gwendolen Road, Leicester, \\ United Kingdom
}

\section{Introduction}

Incidence of Colorectal Cancer: Colorectal cancer (CRC) is the third most common neoplasm worldwide. According to the International Agency for Research on Cancer (IARC), approximately 1.24 million new cases of CRC were detected worldwide in 2008 (Ferlay, et al, 2008). It is the third most common cancer in men (10.0\% of the total) and the second commonest in women $(9.4 \%$ of the total) worldwide. IARC data have shown that more than half of all CRC cases occur in the developed regions of the world i.e. Europe, America and Japan (Ferlay, et al, 2008). In the European Union (EU27) alone 334,000 new cases of CRC were detected in 2008 and approximately 38,000 people were diagnosed with CRC in the UK alone (National UK Statistics). The incidence of CRC is on rise in Europe, particularly in southern and Eastern Europe, where rates were originally lower than in Western Europe (Coleman, et al, 1993 \& Bray, et al, 2004). Contrary to the current trend in Europe, the incidence rate of CRC in the USA has fallen in the last two decades (NCI-SEER, 2006). Epidemiological studies have identified that a rapid trend of 'Westernization', with change in diet and life style has resulted in increased incidence rates of CRC in developing countries (Marchand, et al, 1999, Flood, et al, 2000, Boyle, et al, 2008, \& Ferlay, et al, 2010). The occurrence of CRC is strongly related to age, with nearly $80 \%$ of cases arising in people who are 60 years or older, although there has been a recent increase in incidence in people younger than 60 . The lifetime risk for developing CRC in men is 1 in 16 whereas in women it is 1 in 20 (National Statistics, UK).

\section{The need for improved biomarkers}

The survival and prognosis of patients suffering from CRC depends on the stage of the tumour at time of detection. "Five year survival" significantly reduces from $93 \%$ for localized early cancerous lesions (Dukes A) to $<15 \%$ for advanced metastatic cancers (Dukes D). Unfortunately, approximately one third of patients with CRC have regional or distant spread of their disease at time of diagnosis (Ferlay, et al, 2008). Currently, bowel 
cancer screening programmes in Europe use either flexible sigmoidoscopy (FS) or guaiacbased faecal occult blood testing (FOBT) as the primary screening tool, with the current gold standard colonic imaging modality of colonoscopy being reserved for patients testing positive. Both primary screening tests have proven to be of benefit in reducing the death rate from CRC in randomised controlled trials but are generally considered to lack the desired convenience or accuracy for use as a general screening test (Hewitson, et al, 2007). A comparative study of diagnostic sensitivities of FOBT, faecal immunochemical stool testing (FIT), flexible sigmoidoscopy (FS), colonoscopy and CT colonography (CTC) has revealed $20 \%, 32 \%, 83.3 \% 100 \%$ and $96.7 \%$ sensitivity, respectively for the detection of CRC and advanced adenomas (Graser, et al, 2009) . Endoscopic and radiological diagnostic modalities are expensive and are associated with risks such as bleeding, infection, bowel perforation and exposure to radiation. This explains why there is still a need for an improved, reliable, accurate and non-invasive biomarker for colorectal cancer detection.

\section{Colorectal cancer development}

The development of CRC follows the sequential progression from adenoma to the carcinoma (Vogelstein, et al, 1988). Carcinogenesis pathways for colorectal neoplasia have become much clearer and precise in the past two decades. The common pathway for CRC development is dependent on Adenomatous Polyposis Coli (APC) \& Tumour Protein-53 (TP53) gene mutations and is initiated through WNT signalling (Segditsas, et al, 2006). In this pathway colonic carcinoma originates from the colonic epithelium as a consequence of accumulation of genetic alterations in the tumour suppressor gene TP53 and oncogenic APC genes. The initial genetic alterations result in adenoma formation in which cells exhibit autonomous growth. During the further course of carcinogenesis, intestinal epithelial cells acquire the characteristics of invasion and the potential for metastasis. Another carcinogenesis pathway has recently gained acceptance and is commonly named as the serrated-neoplasia pathway. This pathway is for the most part APC and TP53 independent and shows distinct molecular features of somatic mutations such as BRAF mutation and concordance with high $\mathrm{CpG}$ islands methylation phenotype (CIMP-H), microsatellite instability (MSI+) and MutT homologue 1 (MLH1) methylation (Casey, et al, 2005 \& Spring, et al, 2006,) . Sequential progression of colorectal neoplasia from adenoma to carcinoma highlights that opportunities exist to improve cancer specific survival by altering the natural course of disease development. Such interventions could potentially be chemo preventive for high risk individuals, the early detection of colorectal neoplasia, chemotherapy to down stage the cancer prior to surgical resection and therapy for palliation of symptoms in advanced stage cancer. Recent advances in proteomics and genomics provide a vast amount of information about the role of micro-molecules in several cancer related pathways. These advances have focused on the detection of micro molecules released from tumour cells and their utility as diagnostic biomarkers. The discovery of tumour specific microRNAs (miRNAs) has opened a new era of biomarker research that holds great potential for future cancer detection strategies.

\section{What are MicroRNAs}

MicroRNAs are single-stranded, evolutionarily conserved, small (17-25 ribonucleotides) noncoding (Lee, et al, 1993) RNA molecules. MiRNAs function as negative regulators of 
target genes by directing specific messenger RNA cleavage or translational inhibition through the RNA induced silencing complex (RISC) (Bartel, et al, 2004 \& 2009). So far around 1400 mature human miRNAs have been described in the Sanger miRBase version 17 (An international registry and database for miRNA nomenclature, targets, functions and their implications in different diseases). In the database, each mature miRNA in human and non-human species is assigned a unique identifier number for universal standardization. For example human microRNA 21 is designated as hsa-miR-21. Table 1 summarizes the different types of RNAs by size, mechanism of action and function in human cells.

\begin{tabular}{|c|c|c|c|}
\hline $\begin{array}{l}\text { Types of Non } \\
\text { Coding RNA }\end{array}$ & $\begin{array}{l}\text { Size } \\
\text { No of } \\
\text { Nucleotides }\end{array}$ & Mechanism of Action & Function \\
\hline $\begin{array}{l}\text { MicroRNA } \\
\text { (miRNA) }\end{array}$ & $17-23$ & $\begin{array}{l}\text { RNA induced silencing } \\
\text { complex (RISC) }\end{array}$ & Translational Inhibition \\
\hline $\begin{array}{l}\text { Messanger RNA } \\
\text { (mRNA) }\end{array}$ & $900-1500$ & $\begin{array}{l}\text { Conveys genetic } \\
\text { information from DNA to } \\
\text { the ribosomes }\end{array}$ & Protein synthesis \\
\hline $\begin{array}{l}\text { Small interfering } \\
\text { RNA (SiRNA) }\end{array}$ & $\begin{array}{l}20-25 \\
\text { Double } \\
\text { stranded }\end{array}$ & $\begin{array}{l}\text { RNA interference and } \\
\text { RNA interference related } \\
\text { pathways }\end{array}$ & $\begin{array}{l}\text { Interference with gene } \\
\text { expression }\end{array}$ \\
\hline $\begin{array}{l}\text { Piwi-interacting } \\
\text { RNA (piRNA) }\end{array}$ & $26-31$ & $\begin{array}{l}\text { RNA-protein complex } \\
\text { formation with piwi } \\
\text { proteins }\end{array}$ & $\begin{array}{l}\text { Transcriptional gene } \\
\text { silencing of } \\
\text { retrotransposons and other } \\
\text { genetic elements in germ } \\
\text { line cells }\end{array}$ \\
\hline $\begin{array}{l}\text { Small Nucleolar } \\
\text { RNA (SnoRNA) }\end{array}$ & $70-200$ & $\begin{array}{l}\text { Act as ribonucleoprotein } \\
\text { (RNP) complexes to guide } \\
\text { the enzymatic modification } \\
\text { of target RNAs at sites } \\
\text { determined by RNA:RNA } \\
\text { antisense interactions }\end{array}$ & $\begin{array}{l}\text { Chemical modifications of } \\
\text { other RNAs e,g } \\
\text { methylation, } \\
\text { pseudouridylation }\end{array}$ \\
\hline $\begin{array}{l}\text { Transfer RNA } \\
\text { (tRNAs) }\end{array}$ & $\begin{array}{l}73 \text { to } 93 \\
\text { Clover Leaf }\end{array}$ & $\begin{array}{l}\text { Transfers a specific active } \\
\text { amino acid to a growing } \\
\text { polypeptide chain at the } \\
\text { ribosomal site of Protein }\end{array}$ & $\begin{array}{l}\text { Amino acid carriers and } \\
\text { protein synthesis during } \\
\text { translation. }\end{array}$ \\
\hline $\begin{array}{l}\text { Ribosomal RNA } \\
\text { ( rRNA) }\end{array}$ & $120-5050$ & $\begin{array}{l}\text { Decode mRNA into amino } \\
\text { acids }\end{array}$ & $\begin{array}{l}\text { Protein synthesis in } \\
\text { ribosomes }\end{array}$ \\
\hline
\end{tabular}

Table 1.

\section{MicroRNA biogenesis in human cells}

MiRNAs are mostly transcribed from intragenic or intergenic regions by RNA polymerase II into primary transcripts (pri-miRNAs) of variable length $(1 \mathrm{~kb}-3 \mathrm{~kb})$. In the nucleus PrimiRNA transcript is further processed by the nuclear ribo-nuclease enzyme 'Drosha' thereby resulting in a hairpin intermediate of about 70-100 nucleotides, called pre-miRNA. The pre-miRNA is then transported out of the nucleus by a transporting protein exportin- 5 . 
In the cytoplasm, the pre-miRNA is once again processed by another ribonuclease enzyme 'Dicer' into a mature double-stranded miRNA. The two strands of double stranded miRNA (miRNA/miRNA* complex) are separated by Dicer processing. After strand separation, the mature miRNA strand (miRNA- also called the guide strand) is incorporated into an RNAinduced silencing complex (RISC), whereas the passenger strand, denoted with a star (miRNA $^{*}$ ) is commonly degraded (Hammond, et al, 2000, Lee, et al, 2003, Bohnsack, et al, 2004 \& Thimmaiah, et al, 2005). This miRNA/RISC complex is responsible for miRNA function. If on miRNA cloning or array the passenger strand is found at low frequency (less than $15 \%$ of the guide strand) it is named miR*. However, if both passenger and guide strand are equal in distribution, then these two strands are named $3 p$ and $5 p$ version of miRNA depending on their location to either $5^{\prime}$ or $3^{\prime}$ of the miRNA molecule. In this case both strands can potentially incorporate in RISC complex and have a biological role. Nevertheless, quite a few miRNA* strands are found to be conserved and play an important role in cell homeostasis. However, only recently studies have focussed on the functional role of the miRNA* strand. Well-conserved miRNA* strands may prove important links in cancer regulation networks (Stark, et al, 2007, Okamura, et al, 2008, Zhou, et al, 2010 \& Guo, et al, 2010). Figure 1 illustrates the biogenesis of miRNAs in the cellular nucleous, its transport to cytoplasm, and processing by Drosha and Dicer Enzymes. Figure 1 also illustrates the RISC incorporation of miRNAs for functional activity in different pathways of translational inhibition or activation.

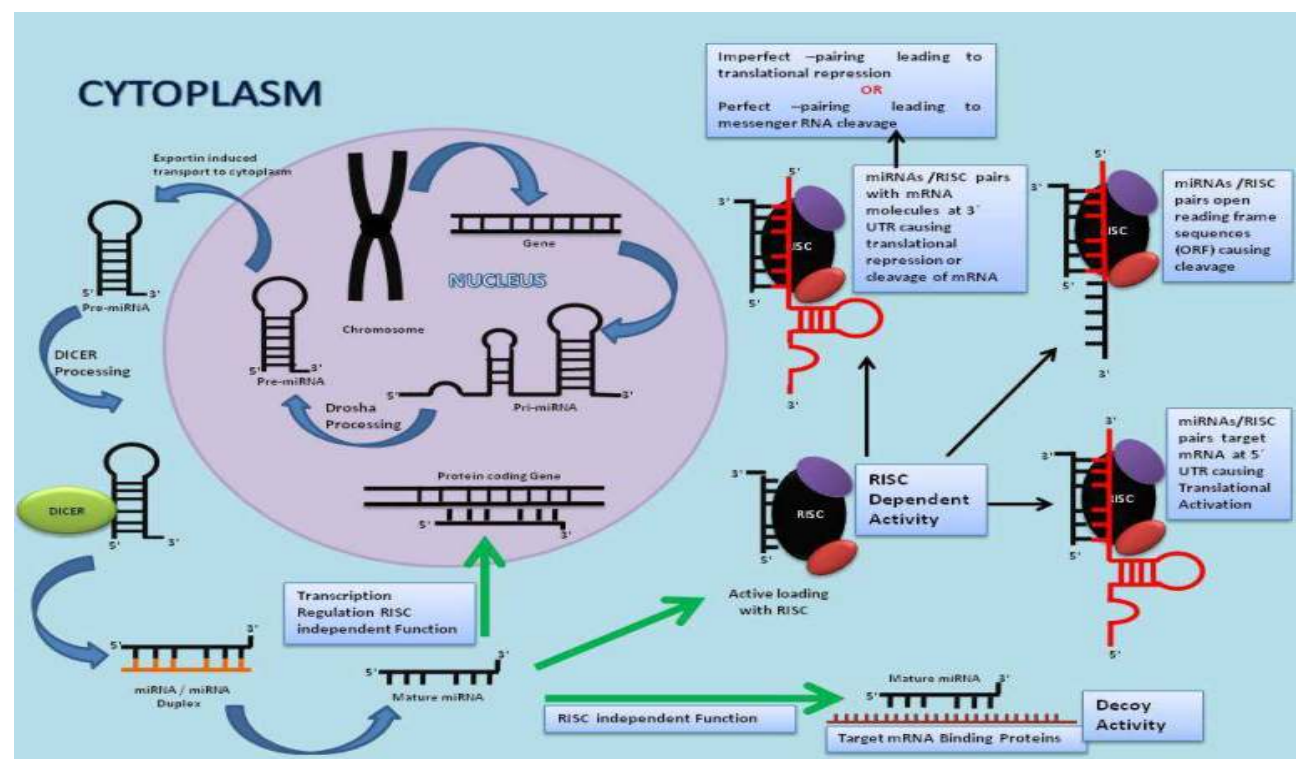

Fig. 1.

\section{Mechanism of action \& cellular function of MicroRNA}

The specificity of miRNA targeting is defined by Watson-Crick complementarities between positions 2 to 8 from the 5 primed end of miRNA sequence with the $3^{\prime}$ untranslated region 
(UTR) of their target mRNAs. When miRNA and its target mRNA sequence show perfect complementarities, the RISC induces mRNA degradation. Should an imperfect miRNAmRNA target pairing occur, translation into a protein is blocked (Bartel, et al, 2004 \& 2009). Regardless of which of these two events occur, the net result is a decrease in the amount of the proteins encoded by the mRNA targets. Each miRNA has the potential to target a large number of genes (on average about 500 for each miRNA family). Conversely, an estimated $60 \%$ of the mRNAs have one or more evolutionarily conserved sequences that are predicted to interact with miRNAs (Friedman, et al, 2009). MiRNAs have been shown to bind to the open reading frame or to the 5' UTR of the target genes and, in some cases, they have been shown to activate rather than to inhibit gene expression (Ørom, et al, 2008). It has also reported that miRNAs can bind to ribonucleoproteins in a seed sequence and a RISCindependent manner and then interfere with their RNA binding functions (decoy activity) (Eiring, et al, 2010). MiRNAs can also regulate gene expression at the transcriptional level by binding directly to the DNA (Khraiwesh, et al, 2010) as illustrated in Figure 1.

\section{Methods of MicroRNA analysis and quantification}

Numerous approaches have been developed to analyze and quantify the expression of miRNAs. A commonly adopted strategy is to perform mass scale expression profiling/signature of miRNAs on a small cohort of patients to identify most significantly dysregulated miRNAs. Expression profiling is usually followed by a validation of selected miRNAs on an independent cohort by using QRT-PCR. Expression profiling has been performed using Hybridization-Microarray, Real Time Polymerase Chain Reaction (QRTPCR) Array and most recently Deep-Sequencing (Meyer, et al, 2010). Most of these approaches are developed against the gold standard 'Northern Blotting'. Each has its unique advantages and disadvantages, such as throughput, sensitivity, ease of use and cost. QRT-PCR can detect very low concentrations of molecules with much superior sensitivity and expenditure of time and money (Chen, et al, 2005). Microarray-based techniques have the advantage of being relatively cost-effective, quick and simple to utilize (Pradervand, et al, 2010). Ultra high throughput miRNA sequencing allows denovo detection and relative quantification of miRNAs, but requires a considerable amount of time and cost for data generation and data analysis (Wang, et al, 2007). A key issue of miRNA detection and quantification is the selection of endogenous controls for relative quantification. In QRT-PCR based detection systems, several small nuclear and small nucleolar RNAs (e.g. RNU6B) are recommended for normalising miRNA expression signature/profiles in tissues, cell lines, and human body fluids. However, RNU6B is heat unstable and rapidly degrades resulting in poor reproducibility of experiments. That's why many researchers have used the invariant and most stable miRNAs as endogenous controls (Meyer, et al, 2010). In order to overcome this problem of normalization in QRTPCR and other detection systems, researchers have used different statistical strategies including: global mean expression; quantile; scaling; and normalizing factor. However, some normalization methods have been challenged whereas others were adapted to the specific nature of miRNA profiling experiments. At present, there is no generally agreed normalization strategy for any of the known detection approaches. Table 2 shows the comparison of different detection systems by practical application, throughput, cost and time expenditure. 


\begin{tabular}{|l|l|l|l|}
\hline Detection Systems & $\begin{array}{l}\text { MicroRNA QRT-PCR } \\
\text { Expression Profiling }\end{array}$ & $\begin{array}{l}\text { MicroRNA- } \\
\text { Array }\end{array}$ & $\begin{array}{l}\text { MicroRNA- } \\
\text { Sequencing }\end{array}$ \\
\hline Method & PCR & Hybridization & Deep Sequencing \\
\hline $\begin{array}{l}\text { Initial RNA } \\
\text { Concentration }\end{array}$ & 10 ng & $100 \mathrm{ng}$ & 250ng \\
\hline Time Required & $<24$ hours & 24-48 hours & $>1$ week \\
\hline Cost & $\begin{array}{l}\text { Low-medium for Pool } \\
\text { Profiling. Even lower } \\
\text { for custom designed } \\
\text { individual assays. }\end{array}$ & $\begin{array}{l}\text { Low-medium for } \\
\text { Pool Profiling }\end{array}$ & High \\
\hline Throughput & Medium-high & High & \begin{tabular}{l} 
Ultra-high \\
\hline Utility
\end{tabular} \\
$\begin{array}{l}\text { Relative and absolute } \\
\text { miRNAs }\end{array}$ & $\begin{array}{l}\text { Relative and } \\
\text { absolute } \\
\text { quantification of } \\
\text { miRNAs }\end{array}$ & $\begin{array}{l}\text { Relative quantification } \\
\text { of known miRNAs. } \\
\text { Identification of } \\
\text { novel miRNA } \\
\text { sequences. }\end{array}$ \\
\hline
\end{tabular}

Table 2.

\section{Role of MicroRNA in colorectal cancer development}

MiRNAs have been shown to play an important role in colorectal cancer oncogenesis, progression, angiogenesis, invasion and metastasis (Lee, et al, 2007, Huang, et al, 2008 \& Liu, et al, 2011). Esquela-Kerscher \& Slack in their review have suggested that the dysregulation of miRNA genes that target mRNAs for tumour suppressor or oncogenes can influence tumourigensis (Esquela-Kerscher, et al, 2006). The miRNA expression profiling studies on colonic tumour and adjacent normal tissue have identified several differentially expressed miRNAs in cancerous tissue. Table 1 summarizes the relatively over-expressed and underexpressed miRNAs studied in CRC tissue from different studies. Studies focussing on the functional and mechanistic involvement of miRNAs in colon cancers have reported that selected groups of distinct miRNAs are commonly and concurrently upregulated or downregulated in colon cancer tissues and are often associated with distinct cytogenetic abnormalities (Xi, et al, 2006, Schepeler, et al, 2008 \& Schetter, et al, 2008). Table 3 shows the summary of dysregulated miRNAs in colorectal tumour tissue compared to adjacent normal colonic mucosa. Over expressed or under expressed miRNAs identified by two or more studies are underlined and the miRNAs with conflicting expression levels in different studies are identified in Bold.

\begin{tabular}{|c|c|c|}
\hline Studies & $\begin{array}{l}\text { Downredulated miRNAs in } \\
\text { CRC tissue }\end{array}$ & $\begin{array}{l}\text { Upregulated miRNAs in CRC } \\
\text { tissue }\end{array}$ \\
\hline Michael, et al, 2003 & $\begin{array}{l}\text { let-7, miR-16, miR-24, } \\
\underline{\mathrm{miR}-26 \mathrm{a}, \mathrm{miR}-102,} \\
\underline{\mathrm{miR}-143}, \underline{\mathrm{miR}-145} \\
\underline{\mathrm{miR}-200 \mathrm{~b}}\end{array}$ & \\
\hline
\end{tabular}




\begin{tabular}{|c|c|c|}
\hline Studies & $\begin{array}{l}\text { Downredulated miRNAs in } \\
\text { CRC tissue }\end{array}$ & $\begin{array}{l}\text { Upregulated miRNAs in CRC } \\
\text { tissue }\end{array}$ \\
\hline Volinia, et al, 2006 & $\begin{array}{l}\text { let-7a-1, miR-9-3, miR-23b, miR- } \\
\text { 138, miR-218 }\end{array}$ & $\begin{array}{l}\text { miR-16, } \frac{\text { miR-17-5p }}{\text { miR-20a, }} \\
\frac{\text { miR-21 }}{\text { 195, miR-29b }}, \underline{\text { miR-199a }}, \underline{\text { miR- }}\end{array}$ \\
\hline Xi, et al, 2006 & $\begin{array}{l}\text { let-7b, let-7 g, miR-26a , miR- } \\
\text { 30a-3p, miR-132, miR-181a, } \\
\text { miR-181b, miR-296, miR-320, } \\
\text { miR-372 }\end{array}$ & $\begin{array}{l}\text { miR-10a, miR-15b , } \underline{\text { miR-23a }}, \\
\underline{\text { miR-25}}, \underline{\text { miR-27a }}, \underline{\text { miR-27b }}, \text { miR- } \\
\text { 30c, miR-107, miR-125a, miR-191, } \\
\underline{\text { miR-200c, miR-339 }}\end{array}$ \\
\hline Bandrés. et al, 2006 & miR-133b, $\underline{\operatorname{miR}-145}$ & $\begin{array}{l}\operatorname{miR}-31, \underline{\operatorname{miR}-96}, \underline{\operatorname{miR}-135 b}, \underline{\operatorname{miR}-} \\
\underline{183}\end{array}$ \\
\hline Akao, et al, 2006 & $\underline{\operatorname{miR}-143}$, miR-145, let -7 & \\
\hline $\begin{array}{l}\text { Nakajima, et al, } \\
2006\end{array}$ & & let-7 g, miR-181b, $\underline{\mathrm{miR}-200 \mathrm{c}}$ \\
\hline Lanza, et al, 2007 & & $\underline{\operatorname{miR}-17-5 p}, \underline{\operatorname{miR}-20}, \underline{\operatorname{miR}-25}, \underline{\text { miR-93-1 }}$ \\
\hline Rossi, et al, 2007 & $\underline{\operatorname{miR}-200 b}, \operatorname{miR}-210, \mathrm{miR}-224$ & 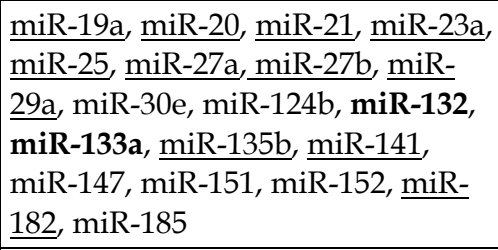 \\
\hline Slaby, et al, 2007 & miR-31， $\underline{\text { miR-143, }} \underline{\text { miR-145 }}$ & $\underline{\operatorname{miR}-21}$ \\
\hline $\begin{array}{l}\text { Monzo, et al, } \\
2008\end{array}$ & $\underline{\operatorname{miR}-145}$ & $\begin{array}{l}\underline{\mathrm{miR}-17-5 \mathrm{p}}, \underline{\mathrm{miR}-21}, \mathbf{m i R}-30 \mathrm{c}, \underline{\mathrm{miR}-} \\
\underline{106 \mathrm{a}}, \mathrm{miR}-107, \underline{\mathrm{miR}-191}, \mathrm{miR}-221\end{array}$ \\
\hline $\begin{array}{l}\text { Schepeler, et al, } \\
2008\end{array}$ & $\begin{array}{l}\text { miR-101， } \underline{\operatorname{miR}-145} \text {, miR-455, } \\
\text { miR-484 }\end{array}$ & $\frac{\mathrm{miR}-20 \mathrm{a}}{513}, \underline{\mathrm{miR}-92}, \mathrm{miR}-510, \mathrm{miR}-$ \\
\hline $\begin{array}{l}\text { Schetter, et al, } \\
2008\end{array}$ & & $\frac{\mathrm{miR}-20 \mathrm{a}}{\mathbf{1 8 1 b}, \mathrm{miR}-21}, \frac{\mathrm{miR}-106 \mathrm{a}-203}{\mathrm{miR}-}$ \\
\hline Arndt, et al, 2009 & $\begin{array}{l}\text { miR-1, miR-10b, miR-30a-3p, } \\
\text { miR-30a-5p, miR-30c, miR-125a, } \\
\text { miR-133a, miR-139, miR-143, } \\
\text { miR-145, miR-195, miR-378*, } \\
\text { miR-422a, miR-422b, miR-497 }\end{array}$ & 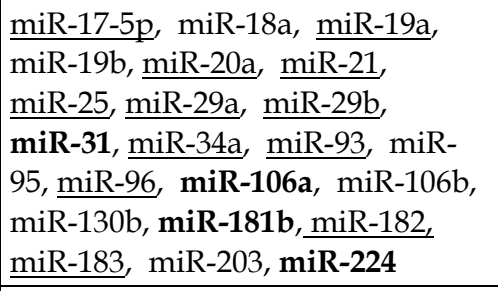 \\
\hline Slattery, et al, 2011 & $\frac{\operatorname{miR}-143}{\operatorname{miR}-215}, \underline{\operatorname{miR}-145}$, miR-192, & 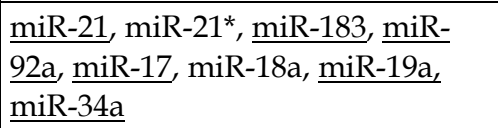 \\
\hline
\end{tabular}

Table 3. 


\section{The use of circulating satellite MicroRNA for colorectal cancer detection}

Recent work by Mitchell \& Gilad (Mitchell, et al, 2008 \& Gilad, et al, 2008) has identified the presence of cancer related miRNAs in the body fluids of patients with different body organ cancers. These tumour-derived miRNAs are present in human serum or plasma in a remarkably stable form and are protected from endogenous ribonuclease activity. Given that aberrantly expressed miRNAs in CRC tissue are secreted into blood, circulating miRNAs can potentially serve as non-invasive markers for CRC detection. In 2008, Chen and colleagues used high-throughput sequencing technique and compared the miRNA expression profiles of patient with CRC and healthy controls (Chen, et al, 2008). MiRNA expression profiles of $\mathrm{CRC}$ and healthy controls were significantly different. However, more than $75 \%$ of the aberrantly expressed miRNAs, detected in the serum of CRC patients were also present in the serum of patients with lung cancer. A similar trend was also observed in another study where expression profiles generated from plasma of breast cancer patients were compared with colorectal cancer and other solid organ cancers (Heneghan, et al, 2010). Identification and quantification of cancer related circulating miRNAs are associated with challenges in terms of sample preparation, experimental design, and pre-analytic variation, selection of diagnostic miRNAs, data normalization and data analysis. Meyer \& Kroch (Meyer, et al, 2010 \& Kroh, et al, 2010) have recently addressed many of these obstacles and provided a guide for effective strategies to overcome these issues.

Preliminary studies ( $\mathrm{Ng}$, et al, 2009, Pu, et al, 2010 \& Cheng, et al, 2011) suggest that colorectal tumour derived miRNAs are present in the circulation at detectable levels and can used as potential biomarkers for colorectal neoplasia detection. These studies used either whole plasma or total RNA extracted from a defined amount of plasma samples collected from healthy controls and diseased patients. QRT-PCR based detection systems were applied to detect selected circulating miRNAs. Selection of miRNAs was based either on results of plasma miRNA expression profiling experiments performed on relatively small cohorts of healthy and diseased patients or highly up regulated miRNAs in CRC tissue. Table 4 summarizes the sensitivity and specificity of different miRNAs investigated for their utility as biomarkers. Results of these studies are very encouraging due to the high sensitivity for detection of CRCs and adenomas. The accuracy of miRNA based detection modalities is much higher than stool based detection modalities and may be comparable with endoscopic modalities. Furthermore, the ability to detect adenomas highlights the potential role of circulating miRNAs in bowel cancer screening. Therefore, in addition to a stand alone blood test for CRC, a miRNA based blood assay can be used as a replacement of FOBT in bowel cancer screening programmes. With its higher sensitivity and specificity, it may prove cost effective and help reduce the need for unnecessary colonic investigations. Table 4 shows the comparison of sensitivity and specificity of different miRNAs for their utility as biomarkers for detection of adenocarcinoma and adenoma*. QRT-PCR based quantification of miRNAs has been the preferred method of study in the majority of these studies.

Though the analysis of circulating miRNAs in CRC patients has identified several diagnostic miRNAs, their diagnostic accuracy is still questionable. This is due to overlapping miRNA expression with other cancers, non-cancerous conditions and variability of individual miRNA expression with stage and grade of tumour. It is possible that common carcinogenesis-related miRNAs are shared by different types of tumours and investigators 


\begin{tabular}{|l|l|lr|l|l|l|}
\hline Tissue \\
Type
\end{tabular}

Table 4.

are detecting cancer-related but not tissue specific miRNAs. Another explanation of the findings is that the detection of miRNAs released into the circulation originates in immune cells which occur as a result of a systemic immune response generated by the tumour causing abnormal proliferation of colonic cells (Dong, et al, 2011). This might also explain the finding of commonly dysregulated miRNAs in patients with CRC and Ulcerative Colitis (Pekow, et al, 2011). Furthermore, studies to date have focused on measuring the circulating levels of either single miRNAs or a subset of the known miRNAs. Due to the above reasons, a single miRNA based detection strategy would be rather ineffective whereas a CRC tissue specific expression signature generated from plasma or serum of patients with CRC and adenoma could be more informative and accurate.

The recent discovery of exosome mediated transport of cancer related miRNAs into the circulation, has shifted the focus of miRNA studies towards the isolation of tissue specific circulating exosomes and their encompassed miRNAs. Exosomes are membrane bound small vesicles (20 to $100 \mathrm{~nm}$ in diameter) of endocytic origin and are released by a variety of cells in both healthy and disease conditions (Théry, et al, 2002 \& Keller, et al, 2006). Exosomes correspond to the internal vesicles of multivesicular bodies (MVBs) and are released in the extracellular environment upon fusion of MVBs with the plasma membrane, (Théry, et al, 2002 \& Cocucci, et al, 2009). Since exosome formation includes two inward budding processes, exosomes maintain the same topological orientation as the cell, with membrane proteins on the outside and some cytosol on the inside. Exosomes contain cytoplasmic proteins, miRNAs and mRNA transcripts (Valadi, et al, 2007).

The topical orientation of exosomal membrane may help in identification of their source by using surface antigen directed antibodies e.g. anti-MHCII. One drawback of this isolation method is that unless all the exosomes contain the specific surface antigen used for the 


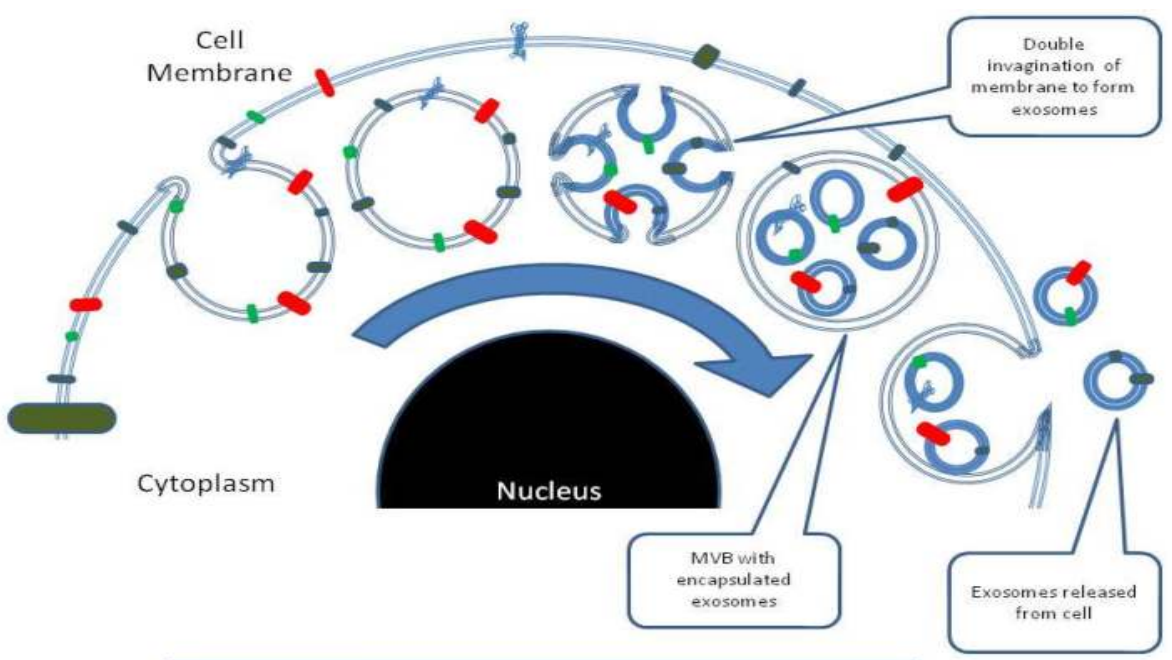

Formation of Exosome in Cell

Fig. 2.

isolation, only a fraction of the exosomes will be isolated. Circulating exosomes can also be isolated based on their size, density and surface proteins. A commonly used method of purifying exosomes involves removal of cells and debris with either a filtration process or by a series of centrifugations (differential centrifugation), followed by a final high speed centrifugation (ultracentrifugation) to pellet the exosomes. Exosomes have a specific density and can be purified by floatation in a sucrose density gradient or by sucrosedeuterium oxide (D2O) cushions. Another purification method is based on exosome size and utilizes chromatography. The size and characterisation of exosomes is performed by using transmission electron microscopy, immune-electronmicroscopy, flow cytometry and dynamic light scattering. Table 5 summarizes the exosome isolation and characterisation methods used by different groups to analyse exosomes specific to colorectal cancer cells and methods of isolation of circulating exosomes for miRNAs analysis for other cancers (Simpson, et al, 2009). There is, however, a growing need for a fast and reliable method that yields a highly purified exosome fraction.

Based on this immunoaffinity strategy, several groups have isolated exosomes from the blood of patients with different cancers and have performed miRNA expression profiles on the total RNA isolated from these purified and probably tumour specific exosomes (Taylor, et al, 2008, Logozzi, et al, 2009 \& Rabinowits, et al, 2009). Patients with cancer are found to have relatively higher quantities of exosome and encompassed miRNAs in the circulation Rabinowits, et al, 2009). The analysis of miRNAs extracted from circulating exosomes in patients with ovarian cancer, has been proven to be equivalent to ovarian tissue biopsies Taylor, et al, 2008). By using a similar approach of isolation and analysis, exosomal miRNAs in colorectal cancer can be evaluated for their diagnostic accuracy and may prove a breakthrough diagnostic modality. 


\begin{tabular}{|c|c|c|c|}
\hline \multicolumn{4}{|c|}{ Isolation and Characterisation of Colorectal Cancer Cell line Exosomes } \\
\hline Studies & $\begin{array}{l}\text { Colorectal } \\
\text { Cancer Cell } \\
\text { lines }\end{array}$ & Isolation method & $\begin{array}{l}\text { Characterisation and Validation of } \\
\text { Exosome }\end{array}$ \\
\hline $\begin{array}{l}\text { Huber, et al, } \\
2005^{69}\end{array}$ & $\begin{array}{l}\text { SW403 } \\
1869 \mathrm{col} \\
\text { CRC28462 }\end{array}$ & $\begin{array}{l}\text { Differential } \\
\text { Centrifugation }\end{array}$ & $\begin{array}{l}\text { Transmission Electron Microscopy } \\
\text { Immune Electron Microscopy } \\
\text { Fluorescence-activated cell sorting } \\
\text { (FACS) } \\
\text { Western Blotting }\end{array}$ \\
\hline $\begin{array}{l}\text { Mathivanan, et } \\
\text { al, } \\
2010^{70}\end{array}$ & LIM1215 & $\begin{array}{l}\text { Filtration, } \\
\text { Diafiltration (5K) } \\
\text { Ultracentrifugation } \\
\text { Immuoaffinity } \\
\end{array}$ & $\begin{array}{l}\text { Transmission Electron Microscopy } \\
\text { Immune Electron Microscopy } \\
\text { Western Blotting }\end{array}$ \\
\hline $\begin{array}{l}\text { Choi, et al, } \\
200771\end{array}$ & HT29 & $\begin{array}{l}\text { Differential } \\
\text { Centrifugation } \\
\text { Diafiltration(100k) } \\
\text { Density Gradient } \\
\end{array}$ & $\begin{array}{l}\text { Transmission Electron Microscopy, } \\
\text { Western Blotting }\end{array}$ \\
\hline $\begin{array}{l}\text { van Nigel, et } \\
\text { al, } 2001^{72}\end{array}$ & $\begin{array}{l}\text { HT29-19A } \\
\text { T84- } \\
\text { DRB1*0401/ } \\
\text { CIITA }\end{array}$ & $\begin{array}{l}\text { Differential } \\
\text { Centrifugation } \\
\text { Density Gradient }\end{array}$ & $\begin{array}{l}\text { Transmission Electron Microscopy, } \\
\text { Immune Electron Microscopy } \\
\text { Western Blotting }\end{array}$ \\
\hline \multicolumn{4}{|c|}{ Isolation and Characterisation of Circulating Exosomes for MicroRNA Analysis } \\
\hline Studies & Cancer Type & Isolation Method & Specific Method/ Technique \\
\hline $\begin{array}{l}\text { Logozzi, et al, } \\
200973\end{array}$ & $\begin{array}{l}\text { Malignant } \\
\text { Melanoma }\end{array}$ & $\begin{array}{l}\text { Ultracentrifugation } \\
\text { and filtration }\end{array}$ & $\begin{array}{l}400 \times \mathrm{g} 20 \mathrm{~min} \text { isolate plasma } \\
1,200 \times \mathrm{x} 20 \mathrm{~min} \\
10,000 \times \mathrm{g} 30 \mathrm{~min} \text { and filter through } \\
0.22 \text { um filter } \\
1,00,000 \times \mathrm{g} 60 \mathrm{~min}\end{array}$ \\
\hline $\begin{array}{l}\text { Rabinowits, } \\
\text { et al, } 2009^{74}\end{array}$ & Lung Cancer & $\begin{array}{l}\text { Immunoaffinity } \\
\text { Ultracentrifugation }\end{array}$ & anti-EpCAM coated Immunobead \\
\hline $\begin{array}{l}\text { Taylor, et al, } \\
200875\end{array}$ & $\begin{array}{l}\text { Ovarian } \\
\text { Cancer }\end{array}$ & $\begin{array}{l}\text { Immunoaffinity } \\
\text { Ultracentrifugation }\end{array}$ & $\begin{array}{l}\text { anti-EpCAM antibody coated } \\
\text { Immunobead }\end{array}$ \\
\hline
\end{tabular}

Table 5.

\section{The use of stool MicroRNAs for detection of colorectal neoplasia}

Colonic epithelium is the most dynamic cell population of the human organism. Highly differentiated colonocytes are continuously shed into the colon of healthy individuals and 
patients with CRC (Brittan, et al, 2004 \& Loktionov, et al, 2007) . It is presumed that exfoliated colonocytes from healthy colon and neoplastic lesions carry important genetic and epigenetic information that could be utilized for subsequent testing, such as the detection of mutant genes or dysregulated mRNAs, proteins and miRNAs (Loktionov, et al, 2009). It is proposed that even small neoplastic loci can alter colonic cell exfoliation rate and may lead to early detection of these lesions (Loktionov, et al, 2007). The effectiveness of an exfoliated colonocyte based detection system requires an efficient isolation of colonocytes while minimizing the amount of background faecal debris. In order to achieve maximum retrieval of colonocytes, strategies that have been employed include density gradient centrifugation and/or immunoaffinity on either homogenized stool samples or scrapings from the stool surface (Loktionov, et al, 2007). However, cell yields are generally very low, often with conspicuous background debris, which makes cell identification difficult and time consuming (Deuter, et al, 1995). Consequently, such preparations would be unsuitable for high-throughput population screening programs (White, et al, 2009). Furthermore, colonocytes shed from a proximal colonic region travel a longer distance and are more exposed to cytolytic agents, thus making them less likely to be preserved and sampled. If this does prove to be a common problem, stool miRNA markers for right-sided CRC will be less effective. There is evidence, from the work of Koga and Colleagues (Koga, et al, 2010) that this is indeed the case. In this study immunomagnetic beads were conjugated with EpCAM monoclonal antibody to isolate colonocytes from stool. Despite the selection of two highly up regulated miRNAs in CRC cells, the sensitivity of detection was approximately $70 \%$ as shown in table 6 . However, the detection rate for left sided colonic and rectal tumour was significantly higher, suggesting the potential utility of exfoliated colonocytes based miRNA assay as an alternative to flexible sigmoidoscopy. It is well established that profound deregulation of apoptosis is a characteristic feature of cancer. As a result of apoptosis, tumour specific proteins and genetic information i.e. DNA, RNA and miRNA are released into the lumen of colon (Ahlquist, et al, 2010). Stool environment is much more complex and hostile than plasma, and human RNA are rapidly degraded and only constitute $<1 \%$ of total stool RNA (Ahlquist, et al, 2010). In contrast with the fast degradation of mRNA, human miRNAs are packed in micro vesicles and are well protected from degradation. The available data indicates that stool miRNA analysis can distinguish

\begin{tabular}{|c|c|c|c|c|c|}
\hline \multirow[t]{2}{*}{ Tissue Type } & \multirow[t]{2}{*}{ Studies } & \multirow[t]{2}{*}{ Participants } & \multirow{2}{*}{$\begin{array}{l}\text { Target } \\
\text { MiRNAs }\end{array}$} & \multicolumn{2}{|c|}{ Diagnostic Accuracy } \\
\hline & & & & $\begin{array}{c}\text { Sensitivity } \\
\%\end{array}$ & $\begin{array}{c}\text { Specificity } \\
\%\end{array}$ \\
\hline \multirow{2}{*}{$\begin{array}{l}\text { Exfoliated } \\
\text { Colonocytes }\end{array}$} & \multirow{2}{*}{$\begin{array}{l}\text { Koga, et al, } \\
2010\end{array}$} & \multirow{2}{*}{$\begin{array}{lc}\text { CRC } & (n=197) \\
\text { Control } & (n=119)\end{array}$} & miR-17-92 & 69.5 & 81.5 \\
\hline & & & miR-135 & 46.2 & 95 \\
\hline Faeces & $\begin{array}{l}\text { Link, et al, } \\
2010\end{array}$ & $\begin{array}{ll}\text { CRC } & (\mathrm{n}=10) \\
\text { Adenoma } & (\mathrm{n}=9) \\
\text { Control } & (\mathrm{n}=10)\end{array}$ & $\begin{array}{l}\text { miR-21 } \\
\text { miR-106 }\end{array}$ & $\begin{array}{l}\text { Distinguish } \\
\text { and carci } \\
\text { healthy cor }\end{array}$ & $\begin{array}{l}\text { d adenomas } \\
\text { mas from } \\
\text { rols } P<0.05\end{array}$ \\
\hline
\end{tabular}

Table 6. 
adenoma and carcinoma from healthy controls (Link, et al, 2010). The detection of miRNAs in stool specimens requires efficient protocols for stool preparation, stool miRNA extraction and quantitative analysis (Ahmed, et al, 2009). The utility of stool miRNAs as a biomarker is still in its infancy; further studies of stool miRNA are needed on larger cohorts to validate its diagnostic accuracy.

In summary, systemic and faecal miRNAs can accurately correlate with disease status and can potentially be used for colorectal cancer detection and screening. Detection of colorectal cancer based on miRNA expression analysis requires extensive pre analytical considerations for sample selection \& processing, isolation of miRNAs, the method of expression analysis, selection of endogenous controls for normalisation and data analysis. Studies performed so far have shown great promise for miRNA based detection of colorectal carcinoma and adenoma. There is, however, a further need to develop and evaluate miRNA based assays before their clinical application.

\section{References}

Ahlquist DA. Molecular detection of colorectal neoplasia. Gastroenterology.2010;138: 21272139

Ahmed FE, Jeffries CD, Vos PW, Flake G, Nuovo GJ, Sinar DR, Naziri W, Marcuard SP. Diagnostic microRNA markers for screening sporadic human colon cancer and active ulcerative colitis in stool and tissue. Cancer Genomics Proteomics. 2009;6(5):281-95.

Akao Y, Nakagawa Y, Naoe T.let-7 microRNA functions as a potential growth suppressor in human colon cancer cells. Biol Pharm Bull. 2006;29(5):903-6.

Akao Y, Nakagawa Y, Naoe T. MicroRNAs 143 and 145 are possible common oncomicroRNAs in human cancers. Oncol Rep. 2006;16(4):845-50

Bandrés E, Cubedo E, Agirre X, Malumbres R, Zárate R, Ramirez N, Abajo A, Navarro A, Moreno I, Monzó M, García-Foncillas J. Identification by Real-time PCR of 13 mature microRNAs differentially expressed in colorectal cancer and non-tumoral tissues. Mol Cancer. 2006.19;5:29

Bartel DP. MicroRNAs: genomics, biogenesis, mechanism, and function. Cell. 2004 23;116(2):281-97

Bartel DP. MicroRNAs: target recognition and regulatory functions.Cell: 2009;136, 215-233.

Bohnsack M T, Czaplinski K \& Gorlich D. Exportin 5 is a RanGTP-dependent dsRNAbinding protein that mediates nuclear export of pre-miRNAs. RNA: 2004(10);185191

Boyle P, Langman J. ABC of colorectal cancer Epidemiology.BMJ.2000; 321:805-808.

Bray F, Atkin W. International cancer patterns in men: geographical and temporal variations in cancer risk and the role of gender. JMHG.2004;1(1):38-46

Brittan M, Wright NA. Stem cell in gastrointestinal structure and neoplastic development. Gut 2004;53:899-910

Casey G, Lindor NM, Papadopoulos N, Thibodeau SN, Moskow J, Steelman S, Buzin CH, Sommer SS, Collins CE, Butz M, Aronson M, Gallinger S, Barker MA, Young JP, Jass JR, Hopper JL, Diep A, Bapat B, Salem M, Seminara D, Haile R; Colon Cancer Family Registry.Conversion analysis for mutation detection in MLH1 and MSH2 in patients with colorectal cancer. JAMA. 2005.16;293(7):799-809 
Chendrimada TP, Gregory RI, Kumaraswamy E, Norman J, Cooch N, Nishikura K, Shiekhattar R. TRBP recruits the Dicer complex to Ago2 for microRNA processing and gene silencing. Nature. 2005;436(7051):740-4.

Chen C, Ridzon DA, Broomer AJ, Zhou Z, Lee DH, Nguyen JT, Barbisin M, Xu NL, Mahuvakar VR, Andersen MR, Lao KQ, Livak KJ, Guegler KJ.Real-time quantification of microRNAs by stem-loop RT-PCR. Nucleic Acids Res.2005; 33:e179

Chen X, Ba Y, Ma L, Cai X, Yin Y, Wang K, Guo J, Zhang Y, Chen J, Guo X, Li Q, Li X, Wang W, Zhang Y, Wang J, Jiang X, Xiang Y, Xu C, Zheng P, Zhang J, Li R, Zhang H, Shang X, Gong T, Ning G, Wang J, Zen K, Zhang J, Zhang CY.Characterization of microRNAs in serum: a novel class of biomarkers for diagnosis of cancer and other diseases. Cell Res. 2008;18(10):997-1006.

Cheng H, Zhang L, Cogdell DE, Zheng H, Schetter AJ, Nykter M, Harris CC, Chen K, Hamilton SR, Zhang W. Circulating plasma MiR-141 is a novel biomarker for metastatic colon cancer and predicts poor prognosis. PLoS One. 2011.17;6(3):e17745

Choi DS, Lee JM, Park GW, Lim HW, Bang JY, Kim YK, Kwon KH, Kwon HJ, Kim KP, Gho YS. Proteomic analysis of microvesicles derived from human colorectal cancer cells. J Proteome Res. 2007;6(12):4646-55

Cocucci E, Racchetti G, Meldolesi J. Shedding microvesicles: artefacts no more. Trends Cell Biol. 2009;19(2):43-51

Coleman MP, Estève J, Damiecki P, Arslan A, Renard H. Trends in cancer incidence and mortality. IARC Sci Publ. 1993; (121):1-806.

Deuter R, Pietsch S, Hertel S, Muller O. A method for preparation of fecal DNA suitable for PCR. Nucleic Acids Res 1995;23:3800-1

Dong $\mathrm{Y}, \mathrm{Wu} \mathrm{WK}, \mathrm{Wu} \mathrm{CW}$, Sung JJ, Yu J, Ng SS. MicroRNA dysregulation in colorectal cancer: a clinical perspective. Br J Cancer. 2011.15;104(6):893-8

Eiring AM, Harb JG, Neviani P, Garton C, Oaks JJ, Spizzo R, Liu S, Schwind S, Santhanam R, Hickey CJ, Becker H, Chandler JC, Andino R, Cortes J, Hokland P, Huettner CS, Bhatia R, Roy DC, Liebhaber SA, Caligiuri MA, Marcucci G, Garzon R, Croce CM, Calin GA, Perrotti D. miR-328 functions as an RNA decoy to modulate hnRNP E2 regulation of mRNA translation in leukemic blasts. Cell. 2010.5;140(5):652-65.

Esquela-Kerscher A, Slack FJ. Oncomirs - microRNAs with a role in cancer. Nat Rev Cancer. 2006;6(4):259-69

Ferlay J, Parkin DM, Steliarova-Foucher E. Estimates of cancer incidence and mortality in Europe in 2008. Eur J Cancer. 2010;46(4):765-81.

Ferlay J, Shin HR, Bray F, Forman D, Mathers C, Parkin DM. Estimates of worldwide burden of cancer in 2008: GLOBOCAN 2008. Int J Cancer.2010;127(12): 2893-2917

Flood DM, Weiss NS, Cook LS, Emerson JC, Schwartz SM, Potter JD. Colorectal cancer incidence in Asian migrants to the United States and their descendants. Cancer Causes Control. 2000;11(5):403-11

Friedman RC, Farh KK, Burge CB, Bartel DP. Most mammalian mRNAs are conserved targets of microRNAs. Genome Res. 2009;19(1):92-105.

Gilad S, Meiri E, Yogev Y, Benjamin S, Lebanony D, Yerushalmi N, Benjamin H, Kushnir M, Cholakh H, Melamed N, Bentwich Z, Hod M, Goren Y, Chajut A. Serum microRNAs are promising novel biomarkers. PLoS One. 2008.5; 3(9):e3148 
Graser A, Stieber P, Nagel D, Schafer C, Horst D, Becker CR, Nikolaou K, Lottes A, Geisbüsch S, Kramer H, Wagner AC, Diepolder H, Schirra J, Roth HJ, Seidel D, Göke B, Reiser MF, Kolligs FT. Comparison of CT colonography, colonoscopy, sigmoidoscopy and faecal occult blood tests for the detection of advanced adenoma in an average risk population. Gut. 2009; 58(2):241-8.

Guo L, Lu Z. The fate of miRNA* strand through evolutionary analysis: implication for degradation as merely carrier strand or potential regulatory molecule? PLoS One. 2010.30; 5(6):e11387

Hammond SM, Bernstein E, Beach D, Hannon GJ. An RNA-directed nuclease mediates posttranscriptional gene silencing in Drosophila cells. Nature. 2000.16; 404(6775):293-6.

Heneghan HM, Miller N, Kelly R, Newell J, Kerin MJ. Systemic miRNA-195 differentiates breast cancer from other malignancies and is a potential biomarker for detecting noninvasive and early stage disease. Oncologist. 2010; 15(7):673-82

Hewitson P, Glasziou P, Irwig L, Towler B, Watson E. Screening for colorectal cancer using the faecal occult blood test Hemoccult. Cochrane Database Syst Rev.2007; 24(1):CD001216.

Huang Q, Gumireddy K, Schrier M, le Sage C, Nagel R, Nair S, Egan DA, Li A, Huang G, Klein-Szanto AJ, Gimotty PA, Katsaros D, Coukos G, Zhang L, Puré E, Agami R. The microRNAs miR-373 and miR-520c promote tumour invasion and metastasis. Nat Cell Biol. 2008; 10(2):202-10.

Huang Z, Huang D, Ni S, Peng Z, Sheng W, Du X Plasma microRNAs are promising novel biomarkers for early detection of colorectal cancer. Int J Cancer. 2010.1; 127(1):11826

Huber V, Fais S, Iero M, Lugini L, Canese P, Squarcina P, Zaccheddu A, Colone M, Arancia G, Gentile M, Seregni E, Valenti R, Ballabio G, Belli F, Leo E, Parmiani G, Rivoltini. Human colorectal cancer cells induce T-cell death through release of proapoptotic microvesicles: role in immune escape. Gastroenterology. 2005; 128(7):1796-804

Keller, S, Sanderson, MP, Stoeck, A. Altevogt, P. Exosomes: from biogenesis and secretion to biological function. Immunol Lett. 2006; 107: 102-108

Khraiwesh B, Arif MA, Seumel GI, Ossowski S, Weigel D, Reski R, Frank W. Transcriptional control of gene expression by microRNAs. Cell. 2010.8; 140(1):111-22.

Koga Y, Yasunaga M, Takahashi A, Kuroda J, Moriya Y, Akasu T, Fujita S, Yamamoto S, Baba H, Matsumura Y MicroRNA expression profiling of exfoliated colonocytes isolated from feces for colorectal cancer screening. Cancer Prev Res (Phila). 2010; 3(11):1435-42

Kroh EM, Parkin RK, Mitchell PS, Tewari M. Analysis of circulating microRNA biomarkers in plasma and serum using quantitative reverse transcription-PCR (qRTPCR).Methods. 2010; 50(4):298-301.

Lanza G, Ferracin M, Gafà R, Veronese A, Spizzo R, Pichiorri F, Liu CG, Calin GA, Croce $\mathrm{CM}$, Negrini M mRNA/microRNA gene expression profile in microsatellite unstable colorectal cancer. Mol Cancer. 2007. 23; 6:54

Lee RC, Feinbaum RL, Ambros V. The C. elegans heterochronic gene lin-4 encodes small RNAs with antisense complementarity to lin-14. Cell. 1993.3; 75(5):843-54.

Lee Y, Ahn C, Han J, Choi H, Kim J, Yim J, Lee J, Provost P, Rådmark O, Kim S, Kim VN. The nuclear RNase III Drosha initiates microRNA processing.Nature. 2003.25; 425(6956):415-9. 
Lee DY, Deng Z, Wang CH, Yang BB. MicroRNA-378 promotes cell survival, tumor growth, and angiogenesis by targeting SuFu and Fus-1 expression. Proc Natl Acad Sci U S A. 2007.18; 104(51):20350-5

Link A, Balaguer F, Shen Y, Nagasaka T, Lozano JJ, Boland CR, Goel A. Fecal MicroRNAs as novel biomarkers for colon cancer screening. Cancer Epidemiol Biomarkers Prev. 2010;19(7):1766-74

Liu M, Lang N, Qiu M, Xu F, Li Q, Tang Q, Chen J, Chen X, Zhang S, Liu Z, Zhou J, Zhu Y, Deng Y, Zheng Y, Bi F. miR-137 targets Cdc42 expression, induces cell cycle G1 arrest and inhibits invasion in colorectal cancer cells. Int J Cancer. 2011.15; 128(6):1269-79.

Loktionov A. Cell exfoliation in the human colon: myth, reality and implications for colorectal cancer screening. Int J Cancer. 2007.1; 120(11):2281-9.

Loktionov A, Bandaletova T, Llewelyn AH, Dion C, Lywood HG, Lywood RC, Rockall TA, Stebbing JF, Broughton M, Caffarey S, Marks CG. Colorectal cancer detection by measuring DNA from exfoliated colonocytes obtained by direct contact with rectal mucosa. Int J Oncol. 2009; 34(2):301-11.

Logozzi M, De Milito A, Lugini L, Borghi M, Calabrò L, Spada M, Perdicchio M, Marino ML, Federici C, Iessi E, Brambilla D, Venturi G, Lozupone F, Santinami M, Huber V, Maio M, Rivoltini L, Fais S. High levels of exosomes expressing CD63 and caveolin1 in plasma of melanoma patients. PLoS One. 2009; 4(4):e5219

Marchand L. Combined influence of genetic and dietary factors on colorectal cancer incidence in Japanese Americans. J Natl Cancer Inst Monogr, 1999. 26: p. 101-105.

Mathivanan S, Lim JW, Tauro BJ, Ji H, Moritz RL, Simpson RJ. Proteomics analysis of A33 immunoaffinity-purified exosomes released from the human colon tumor cell line LIM1215 reveals a tissue-specific protein signature. Mol Cell Proteomics. 2010 Feb;9(2):197-208

Meyer SU, Pfaffl MW, Ulbrich SE. Normalization strategies for microRNA profiling experiments: a 'normal' way to a hidden layer of complexity? Biotechnol Lett. 2010 ;32(12):1777-88

Michael MZ, O' Connor SM, van Holst Pellekaan NG, Young GP, James RJ. Reduced accumulation of specific microRNAs in colorectal neoplasia. Mol Cancer Res. 2003 ;1(12):882-91.

Mitchell PS, Parkin RK, Kroh EM, Fritz BR, Wyman SK, Pogosova-Agadjanyan EL, Peterson A, Noteboom J, O'Briant KC, Allen A, Lin DW,Urban N, Drescher CW, Knudsen BS, Stirewalt DL, Gentleman R,Vessella RL, Nelson PS, Martin DB, Tewari M (2008) Circulating microRNAs as stable blood-based markers for cancer detection. Proc Natl Acad Sci USA 105: 10513-10518

Monzo M, Navarro A, Bandres E, Artells R, Moreno I, Gel B, Ibeas R, Moreno J, Martinez F, Diaz T, Martinez A, Balagué O, Garcia-Foncillas J. Overlapping expression of microRNAs in human embryonic colon and colorectal cancer. Cell Res. 2008;18(8):823-33.

Nakajima G, Hayashi K, Xi Y, Kudo K, Uchida K, Takasaki K, Yamamoto M, Ju J. Noncoding MicroRNAs hsa-let-7g and hsa-miR-181b are Associated with hemoresponse to S-1 in Colon Cancer. Cancer Genomics Proteomics. 2006;3(5):317324

National Cancer Institute. Surveillance, Epidemiology and End Results (SEER) 2006. 
Ng EK, Chong WW, Jin H, Lam EK, Shin VY, Yu J, Poon TC, Ng SS, Sung JJ. Differential expression of microRNAs in plasma of patients with colorectal cancer: a potential marker for colorectal cancer screening. Gut. 2009;58(10):1375-81

Okamura K, Phillips MD, Tyler DM, Duan H, Chou YT, Lai EC. The regulatory activity of microRNA* species has substantial influence on microRNA and 3' UTR evolution. Nat Struct Mol Biol. 2008;15(4):354-63

Ørom UA, Nielsen FN, \& Lund AH. MicroRNA-10a binds the 5'UTR of ribosomal protein mRNAs and enhances their translation. Mol. Cell: 2008(4); 460-471

Pekow JR, Dougherty U, Mustafi R, Zhu H, Kocherginsky M, Rubin DT, Hanauer SB, Hart J, Chang EB, Fichera A, Joseph LJ, Bissonnette M. miR-143 and miR-145 are downregulated in ulcerative colitis: Putative regulators of inflammation and protooncogenes. Inflamm Bowel Dis. 2011. doi: 10.1002/ibd.21742

Pradervand S, Weber J, Lemoine F, Consales F, Paillusson A, Dupasquier M, Thomas J, Richter H, Kaessmann H, Beaudoing E, Hagenbuchle O, Harshman K. Concordance among digital gene expression, microarrays, and qPCR when measuring differential expression of microRNAs. Biotechniques.2010;48:219-222

$\mathrm{Pu}$ XX, Huang GL, Guo HQ, et al. Circulating miR-221 directly amplified from plasma is a potential diagnostic and prognostic marker of colorectal cancer and is correlated with p53 expression. J Gastroenterol Hepatol. 2010;25(10):1674-80

Rabinowits G, Gerçel-Taylor C, Day JM, Taylor DD, Kloecker GH. Exosomal microRNA: a diagnostic marker for lung cancer. Clin Lung Cancer. 2009;10(1):42-6

Rossi L, Bonmassar E, Faraoni I.Modification of miR gene expression pattern in human colon cancer cells following exposure to 5-fluorouracil in vitro. Pharmacol Res. 2007;56(3):248-53

Schepeler T, Reinert JT, Ostenfeld MS, Christensen LL, Silahtaroglu AN, Dyrskjøt L, Wiuf C, Sørensen FJ, Kruhøffer M, Laurberg S, Kauppinen S, Ørntoft TF, Andersen CL. Diagnostic and prognostic microRNAs in stage II colon cancer. Cancer Res. 2008.1;68(15):6416-24.

Schetter AJ, Leung SY, Sohn JJ, Zanetti KA, Bowman ED, Yanaihara N, Yuen ST, Chan TL, Kwong DL, Au GK, Liu CG, Calin GA, Croce CM, Harris CC. MicroRNA expression profiles associated with prognosis and therapeutic outcome in colon adenocarcinoma. JAMA. 2008.30;299(4):425-36

Segditsas S, Tomlinson I. Colorectal cancer and genetic alterations in the Wnt pathway. Oncogene. 2006.4;25(57):7531-7

Simpson RJ, Lim JW, Moritz RL, Mathivanan S. Exosomes: proteomic insights and diagnostic potential. Expert Rev Proteomics. 2009;6(3):267-83

Slaby O, Svoboda M, Fabian P, Smerdova T, Knoflickova D, Bednarikova M, Nenutil R, Vyzula R.Altered expression of miR-21, miR-31, miR-143 and miR-145 is related to clinicopathologic features of colorectal cancer. Oncology. 2007;72(5-6):397-402

Slattery ML, Wolff E, Hoffman MD, Pellatt DF, Milash B, Wolff RK MicroRNAs and colon and rectal cancer: differential expression by tumor location and subtype. Genes Chromosomes Cancer. 2011;50(3):196-206

Spring KJ, Zhao ZZ, Karamatic R, Walsh MD, Whitehall VL, Pike T, Simms LA, Young J, James M, Montgomery GW, Appleyard M, Hewett D, Togashi K, Jass JR, Leggett BA. High prevalence of sessile serrated adenomas with BRAF mutations: a 
prospective study of patients undergoing colonoscopy. Gastroenterology.2006; 131(5):1400-7.

Stark A, Kheradpour P, Parts L, Brennecke J, Hodges E, Hannon GJ, Kellis M. Systematic discovery and characterization of fly microRNAs using 12 Drosophila genomes. Genome Res. 2007;17(12):1865-79

Taylor DD, Gercel-Taylor C. MicroRNA signatures of tumor-derived exosomes as diagnostic biomarkers of ovarian cancer. Gynecol Oncol. 2008;110(1):13-21

Théry, C, Zitvogel, L and Amigorena, S. Exosomes: composition, biogenesis and function. Nat Rev Immunol. 2002; 2: 569-579

Valadi H, Ekström K, Bossios A, Sjöstrand M, Lee JJ, Lötvall JO. Exosome-mediated transfer of mRNAs and microRNAs is a novel mechanism of genetic exchange between cells. Nat Cell Biol. 2007; 9(6):654-9

van Niel G, Raposo G, Candalh C, Boussac M, Hershberg R, Cerf-Bensussan N, Heyman M. Intestinal epithelial cells secrete exosome-like vesicles. Gastroenterology. 2001 ;121(2):337-49

Vogelstein B, Fearon ER, Hamilton SR, Kern SE, Preisinger AC, Leppert M, Nakamura Y, White R, Smits AM, Bos JL. Genetic alterations during colorectal-tumor development. N Engl J Med. 1988; 319(9):525-32

Volinia S, Calin GA, Liu CG, Ambs S, Cimmino A, Petrocca F, Visone R, Iorio M, Roldo C, Ferracin M, Prueitt RL, Yanaihara N, Lanza G, Scarpa A, Vecchione A, Negrini M, Harris CC, Croce CM. A microRNA expression signature of human solid tumors defines cancer gene targets.Proc Natl Acad Sci U S A. 2006.14;103(7):2257-61

Wang H, Ach RA, Curry B. Direct and sensitive miRNA profiling from low-input total RNA. RNA. 2007;13:151-159.

White V, Scarpini C, Barbosa-Morais NL, Ikelle E, Carter S, Laskey RA, Miller R, Coleman $\mathrm{N}$. Isolation of stool-derived mucus provides a high yield of colonocytes suitable for early detection of colorectal carcinoma. Cancer Epidemiol Biomarkers Prev. $2009 ; 18(7): 2006-13$

Xi Y, Formentini A, Chien M, Weir DB, Russo JJ, Ju J, Kornmann M, Ju J. Prognostic Values of microRNAs in Colorectal Cancer . Biomark Insights. 2006;2:113-121

Zhou H, Huang X, Cui H, Luo X, Tang Y, Chen S, Wu L, Shen N. miR-155 and its star-form partner miR-155* cooperatively regulate type I interferon production by human plasmacytoid dendritic cells. Blood. 2010.23;116(26):5885-94. 


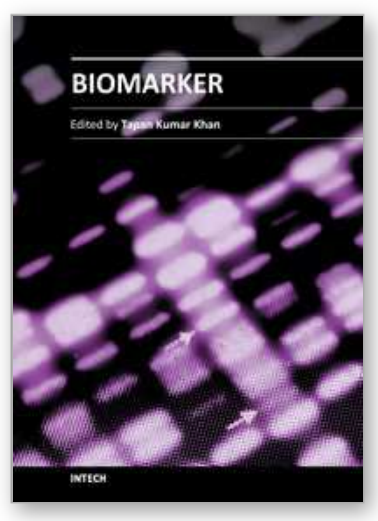

\author{
Biomarker \\ Edited by Prof. Tapan Khan
}

ISBN 978-953-51-0577-0

Hard cover, 392 pages

Publisher InTech

Published online 27, April, 2012

Published in print edition April, 2012

Clinicians, scientists, and health care professionals use biomarkers or biological markers as a measure of a person's present health condition or response to interventions. An ideal -biomarker should have the following criteria: (I) ability to detect fundamental features of the disease, (II) ability to differentiate from other closely related diseases, (III) ability to detect early stages and stages of progression, (IV) the method should be highly reliable, easy to perform and inexpensive, and (V) sample sources should be easily accessible from body. Most of the chapters in this book follow the basic principle of biomarkers.

\title{
How to reference
}

In order to correctly reference this scholarly work, feel free to copy and paste the following:

Muhammad Imran Aslam, Maleene Patel, Baljit Singh, John Stuart Jameson and James Howard Pringle (2012). MicroRNAs are Novel Biomarkers for Detection of Colorectal Cancer, Biomarker, Prof. Tapan Khan (Ed.), ISBN: 978-953-51-0577-0, InTech, Available from:

http://www.intechopen.com/books/biomarker/micrornas-are-novel-biomarkers-for-colorectal-cancer-detection

\section{INTECH}

open science / open minds

\section{InTech Europe}

University Campus STeP Ri

Slavka Krautzeka 83/A

51000 Rijeka, Croatia

Phone: +385 (51) 770447

Fax: +385 (51) 686166

www.intechopen.com

\section{InTech China}

Unit 405, Office Block, Hotel Equatorial Shanghai

No.65, Yan An Road (West), Shanghai, 200040, China 中国上海市延安西路65号上海国际贵都大饭店办公楼 405 单元

Phone: +86-21-62489820

Fax: +86-21-62489821 
(C) 2012 The Author(s). Licensee IntechOpen. This is an open access article distributed under the terms of the Creative Commons Attribution 3.0 License, which permits unrestricted use, distribution, and reproduction in any medium, provided the original work is properly cited. 